\title{
IMPACT OF RENEWABLE ENERGY CONSUMPTION ON ECONOMIC GROWTH: EVIDENCE FROM EUROPEAN UNION COUNTRIES
}

\author{
Georgeta SOAVA $^{1^{*}}$, Anca MEHEDINTU ${ }^{1}$, Mihaela STERPU ${ }^{2}$, \\ Mircea RADUTEANU ${ }^{3}$ \\ ${ }^{1}$ Department of Statistics and Economic Informatics, Faculty of Economics and \\ Business Administration, University of Craiova, 13 A. I. Cuza, Craiova 200585, Romania \\ ${ }^{2}$ Department of Mathematics, Faculty of Sciences, University of Craiova, \\ 13 A. I. Cuza, Craiova 200585, Romania \\ ${ }^{3}$ Procurement Directorate, University of Craiova, 13 A. I. Cuza, Craiova 200585, Romania
}

Received 16 September 2017; accepted 10 February 2018

\begin{abstract}
This study examines the causal relationship between economic growth and renewable energy consumption using data for 28 countries of European Union, taken from Eurostat database for years from 1995 to 2015. In addition, motivated by EU Directive 2009/28/EC, the tendency of the share of renewable energy consumption into the final energy consumption is analysed. Various panel data techniques implemented in EViews are used. The empirical results suggest a positive impact of renewable energy consumption on economic growth, and emphasize bidirectional or unidirectional Granger causalities between the two macroeconomic indicators, for each country in the panel. These results justify the political decisions of EU concerning the necessity of increasing the renewable energy consumption, and prove that this type of energy consumption has a strong positive impact on economic growth. Thus, the inclusion of such policies in future EU and national strategies is further motivated. Finally, by means of linear regression, an increasing trend was found for the ratio between renewable energy consumption and final energy consumption for all but one of the EU countries.
\end{abstract}

Keywords: renewable energy consumption, final energy consumption, economic growth, panel countries, Granger causality, FMOLS.

JEL Classification: C21, O11, Q43.

\section{Introduction}

The 2015 Paris Agreement, the world's first comprehensive agreement on climate change, has formalized European Union's (EU) target to reduce greenhouse gas emissions by at least

\footnotetext{
${ }^{\star}$ Corresponding author. E-mail: georgetasoava@yahoo.ro
} 
$40 \%$ by 2030 , which called on the EU members to adopt strong measures in order to support renewable energy sources (European Parliament, 2016).

The European Parliament is constantly calling for the use of energy from renewable sources, and thus, by means of its resolution adopted in June 2016, has suggested to the Commission to increase up to $30 \%$ the EU's target on energy consumption from renewable sources so that it can be reached through individual targets of the member states. Therefore, in 2016, more than one quarter of the total production of primary energy within the EU-28 came from renewable energy sources and the increase in primary production using renewable energy sources exceeded the share of total primary energy production from other sources of energy (Eurostat, Statistics-explained, 2017).

The European Union, by means of the Intelligent Energy Europe Programme, is at the forefront and holds a key role in promoting renewable energy, and has built global leadership in terms of the technologies used for producing energy from renewable sources (holding 40\% of the patents in the field of renewable energy at a global level and almost half of the global capacity for primary production of energy using renewable sources). Thus, it aims to provide new options in order to ensure sufficient and reliable energy supply at reasonable costs (IEA, 2015).

Starting from the European Commission's decisions on increasing renewable energy consumption, the overall objective of this paper is to analyze the impact of the increase of renewable energy consumption on the development of the EU countries, thus implicitly on the Gross Domestic Product (GDP) of these countries. To this aim, the study realized in the paper was carried out in two directions: firstly, we analyze the impact of final energy consumption from renewable sources (FECRE) on the GDP of each EU country, and secondly, we analyze the evolution of the ratio of FECRE in the Final Energy Consumption (FEC).

For this purpose we collected the information provided by Eurostat for the period 19952015 for the 28 EU members on the evolution of three macroeconomic indicators: GDP, final energy consumption and final consumption of renewable energy. We analyze these series of data using the EViews 9 econometric software package.

The remaining part of the paper is organized as follows: Section 1 discusses a brief review of literature on empirical studies concerning final energy consumption or renewable energy consumption and economic growth, Section 2 describes the empirical models, estimation methodology and the data source, Section 3 presents empirical investigation and results and the last section concludes the study.

\section{Literature review}

A good energy policy is essential for the economic development of any country, as energy is intrinsically linked to GDP, so energy policy influences more or less how European countries economy performs.

GDP as a macroeconomic indicator measures economic activity and indicates the strength of an economy by determining the value of all the final goods and services produced within an economy over a given period of time. It can be considered to be the most widely used unit of measure for the overall size of an economy. GDP growth is an indication of a prosperous economy. 
Generally, the GDP is calculated using three methods: value added method (or production method), expenses method (or the use of final production) and revenue method.

In this paper, we chose to work with the GDP determined by the expenditure method, expressed value at market prices (millions euro), being the only possibility of summing up heterogeneous goods made in the national economy. Expression of the GDP at current market prices eliminates differences between the prices in different countries and allows for widespread use as a tool for comparing living standards or monitoring the convergence process in the European Union.

The main components of GDP by using this method are: private consumption $(C)$, government spending $(G)$, gross investment $(I)$ and net exports (export $(X)$ - import $(M)$ ). The calculation formula is:

$$
G D P=C+G+I+(X-M)
$$

The evolution of GDP is largely influenced by the evolution of final consumption as a sum of the two fundamental components - private consumption $(C)$ and public consumption $(G)$.

In the final consumption, the evolution of final energy consumption is of particular importance, as energy contributes to the stimulating of growth and economic development, and there is a dynamic causality between energy in general and economic growth (Wada, 2017).

A multitude of authors have studied the relationship between GDP and energy consumption by providing a wide range of results in terms of causality, statistically highlighting either a one-way causality, a bidirectional causality or none.

Such analysis were performed in (Anwar, Arshed, \& Nabeela Kousar, 2017) on a panel of 29 OIC countries, data period 1990-2014; in (Alper, \& Oguz, 2016) on a panel of 8 eastcentral European countries, data period 1990-2009; in (Sadorsky, 2009) on a panel of 18 emerging countries, data period 1990-2003; in (Bhattacharya, M., Paramati, Ozturk, \& Bhattacharya, S., 2016) on a panel of top 38 countries, data period 1990-2003; in (Inglesi-Lotz, 2016) on a panel of OEDC countries, data period 1990-2010; in (Bozkurt, \& Destek, 2015) on a panel of OEDC countries, data period 1980-2012; in (Tugcu, Ozlturk, \& Aslain, 2012) on a panel G-7 countries, in (Okyay, Ebru, \& Fatih, 2014) on a panel of developed countries in Europe, data period 1990-2011; in (Chontanawat, Hunt, \& Pierse, 2008) on a panel of 100 countries, data period 1960-2000 or 1971-2000.

Similar studies for the case of individual countries and for different periods of time can be found for Saudi Arabia (Wada, 2017), for China (Lin, \& Moubarak, 2014), for Turkey (Ocal, \& Aslan, 2013), for Brazil (Pao, \& Fu, 2013), for U.S. (Stern, 2000; Yildirim, Sarac, \& Aslan, 2012), for Lithuania (Bobinaite, Juozapaviciene, \& Konstantinaviciute, 2011).

On the other hand, the energy system perspective at European and world level must also be examined in the light of the current climate change, with particular emphasis on the role of renewable technologies (Dalla Longa, \& van der Zwaan, 2017). Given these issues, we thought it would be appropriate to analyze the impact of renewable energy consumption on GDP and evolution of the share of renewable energy consumption in final energy consumption for the countries in EU.

In recent years, countries across the globe have been trying to reduce $\mathrm{CO}_{2}$ emissions by cutting their energy consumption and by switching their energy production. 
The European Union has long been the world leader in the promotion and development of renewable energy, coordinating efforts to combat climate change, encourage the shift to a low-carbon economy and stimulate economic growth great potential. One of the main policy objectives of the European Commission is for the EU to become number one in the world in the field of renewable energy sources.

The current framework for 2020 sets a target of $20 \%$ of EU energy consumption from renewable sources, $27 \%$ for 2030 , given that there has been a rapid increase in the use of renewable energy sources, from 10.4\% in 2007 to $17 \%$ in 2015 (Directive 2009/28/EC).

Renewable energy production will continue to grow rapidly in the coming years, owing to lower production costs, so it is estimated that in 2040 they will account for $70 \%$ of Europe's electricity production (BNEF, 2016).

The main benefits of renewable energy are: reduction of greenhouse gas emissions, diversification of energy sources and reduction of dependence on fossil fuels (especially oil and gas), greater energy diversity, employment in the EU by creating jobs in new 'green' technologies (Gasparatos, Doll, Esteban, Ahmed, \& Olang, 2017).

Rising GDP means increasing purchasing power, so people can buy more products but the price of those goods is largely determined by the energy used in their production.

The correlation between energy consumption, national income and quality of life was analyzed by Ozturk (2017), who highlighted the importance of the role of electricity in final consumption but also the role of renewable sources in final energy consumption for a developing country.

Following Rafiq and Salim (2009) "all the countries may initiate environmental policies aimed at decreasing energy intensity, increasing energy efficiency, developing a market for emission trading".

The benefits and the need for the transfer of renewable energy technologies in developing countries was highlighted by Mardani et al. (2015) following the multi-criteria evaluation of alternatives of development of new energy systems.

Several studies have been performed to show the relationship between renewable energies consumption and economic growth. Various research analyzed data from a wide variety of countries or regions, considered either individually or as groups, following certain criteria. The empirical results found also vary between countries and within regions, and all these findings have important policy implications for the countries concerned (Rafiq, \& Salim, 2011).

The relationship between energy consumption and economic growth was analyzed for 22 OECD countries (Organisation for Economic Co-operation and Development) over the period 1960-2005 in (Aslan, 2013). The results of the study show that while in most cases there is a strong relationship that starts from economic growth to energy consumption, the strongest relationship from energy consumption to economic growth is shown only for Iceland and Portugal.

Apergis and Payne have published several papers examining the relationship between renewable energy consumption and economic growth for different groups of countries. They used cointegration tests, panel error correction models, and Granger-causality tests to determine the long-run relationships and direction of causality between renewable energy 
consumption and economic growth. Their studies use a production model with real GDP as dependent variable, and including renewable energy consumption, gross fixed capital formation, and total labor force as independent variables (Apergis, \& Payne, 2010a, 2010b, 2011a, 2011b, 2012).

Starting from the above-mentioned elements, in this paper we analyze the relationship between FEC, FECRE and GDP at market prices.

Final energy consumption from all resources includes the following categories: solid fuels, total oil products, gas, nuclear heat, renewable energies, electrical energy and waste (nonrenewable).

Final energy consumption from renewable resources includes: wind energy, solar (thermal, photovoltaic and concentrate), hydroelectric power, tidal power, geothermal energy, biofuels and the renewable part of waste. Final energy consumption is expressed in thousand tons of oil equivalent (TOE).

The survey is based on indicators taken from the Eurostat database for the period 19952015 for the $28 \mathrm{EU}$ member states. The data available from Eurostat show that the renewable energy consumption prior to 1995 was statistical insignificant in the final energy consumption. The energy consumption from renewable resources began to increase as a consequence to several political decisions emerging at United Nations Conference on Environment and Development (Rio de Janeiro, 1992) that promoted the concept of sustainable development. The Maastricht Treaty on European Union, amended at Amsterdam in 1997, assumed this concept, thus the increase of energy consumption from renewable resources became a major objective, aimed to protect the environment and decrease carbon dioxide emissions. Furthermore, a major political change started in 1989 in Central and Eastern Europe countries (now EU members), thus until 1995 a transition period in the social, political and economic development of these countries occurred. These facts justify the 1995 threshold in the analyzed data.

The data on which the study was based are organized in a two-dimensional form, namely:

- cross-section data - which contain information on the value of the three analysed indicators (GDP, FEC and FECRE) at a given time (annually) for the $28 \mathrm{EU}$ member states;

- time series data - which contain information on the value of each of the three analysed indicators (GDP, FEC and FECRE), obtained between 1995 and 2015, for the 28 EU member states.

Models analysis on these data, based on classic regression, show that important properties of time series data can be more restrictive than similar properties for cross-section data.

By combining the two dimensions, the data series for the three indicators will be organized as panel - containing information on the value of the three indicators analyzed (GDP, FEC and FECRE), obtained between 1995 and 2015, for the 28 member countries of the EU.

The use of panel data structure benefits of advantages as: estimation of relations in dynamics, incorporating the time dimension for cross-section data and space size for time series, increased efficiency for the estimating of regression models by sample size, increased heterogeneity, reduced collinearity, the ability to control fixed individual effects - which is common to a country over time, but which may vary between the analyzed countries, the ability to model temporal effects without shifting due to aggregation. 


\section{Models and methodology}

\subsection{Models}

In order to investigate the impact of renewable energy consumption on economic growth, this study uses a linear regression model:

$$
L G D P_{i t}=\alpha_{i}+\beta_{i} L F E C R E_{i t}+u_{i t},
$$

where $i=1, \ldots, N$, the index of a country in the panel, $t=1, \ldots, T$, refers to the time period, while $L G D P_{i t}, L F E C R E_{i t}$ represent natural logarithms of real GDP and final energy consumption from renewable sources for the country $i$ at the time $t$, respectively. The terms $\alpha_{i}, \beta_{i}$ are unknown parameters, to be estimated, while $u_{i t}$, are the error terms. Variables in natural logarithms can be interpreted in growth rate after taking the first difference into account.

Derived from a simplified neoclassical production function type model, this model was used by Apergis and Danuletiu (2014) to show the long-run positive causality running from renewable energy to real GDP, for a total sample of data for 80 countries, including several countries from EU.

The second part of the study aims to analyze the evolution of the annual share of final energy consumption from renewable sources in final energy consumption. To this aim we consider the linear regression model, without intercept:

$$
F E C R E_{i t}=\gamma_{i} F E C_{i t}+\varepsilon_{i t},
$$

where $i=1, \ldots, N$, is the index of a country in the panel, $t=1, \ldots, T$, refers to the time period, while $F E C R E_{i t}, F E C_{i t}$ represent final energy consumption from renewable sources and final energy consumption for the country $i$ at the time $t$, respectively. The terms $\gamma_{i}$ are unknown parameters, to be estimated, while $\varepsilon_{i t}(i=1, \ldots, N)$ are the error terms. Evidently, the estimates of regression coefficients $\gamma_{i}$ constitute statistic estimates for the ratio $\frac{F E C R E_{i}}{F E C_{i}}$.

\subsection{Econometric methodology}

The above theoretical models will be estimated using panel data techniques, with the aid of EViews 9 software product.

The analysis of the first model is performed in four steps. Firstly, two different unit root tests are used to investigate whether the variables are stationary or not and the order of integration of the variables. We used Augmented Dickey-Fuller (ADF) (Dickey, \& Fuller, 1981) and the Phillips-Perron (PP) (Phillips, \& Perron, 1988) test to this purpose. Secondly, when all of the series are found to be integrated of the same order, we test the co-integration relationship between the variables in Eq. (1) using the Johansen maximum likelihood method (Johansen, \& Juselius, 1990) and Pedroni cointegration test (Pedroni, 2004). The existence of cointegration indicates that there are long-run equilibrium relationships among the variables, and thereby, Granger causality exists among them in at least one direction (Engle, \& Granger, 
1987). Given the presence of potential two-way relationships between analyzed variables, the estimation of a VAR model to test causality hypotheses is more reliable than that of a single equation model (Salim, \& Bloch, 2009).

Next, the parameter estimates for the regression equations (1) are evaluated using the fully modified least square (FMOLS) regression method (Phillips, \& Hansen, 1990). This cointegration equation can work with variables that are stationary at different levels. An analysis of the estimation errors using the Jarque and Bera test (Jarque, \& Bera, 1980) for normality is also performed.

Finally, the Granger causality test is used to find unidirectional or bidirectional causalities between the real GDP and the renewable energy consumption.

The analysis of the second model also involves statistic tests similar to the ones used for the first model.

\subsection{Data analysis}

The empirical analysis is based on a panel of 28 countries of UE during the 1995-2015 period. We use a series of final energy consumption and GDP data from the Eurostat. Table 1 and 2 presents descriptive statistics of the series for each country.

The GDP series data follow a normal distribution for all countries. Germany has a GDP that is higher than the regional average at 2,382,533 million euro with a standard deviation of 330,925.9. In contrast, Malta has an average GDP in market prices 5,445.962 million euro. This is the lowest figure amongst all the countries, with a standard deviation of 1,766.366. Distribution shows positive asymmetry at all states, which means that during the analyzed period, GDP had a trend of positive growth, and kurtosis has a value less than 3 in all countries, i.e. the distribution is flatter than the normal curve (platykurtic), except for United Kingdom which has a sharper distribution than the normal curve (leptokurtic) (see Table 1).

Table 1. Descriptive statistics: GDP at market prices - million euro

\begin{tabular}{|l|c|c|c|c|c|c|c|}
\hline \multicolumn{1}{|c|}{ Country } & Mean & Maximum & Minimum & Std. Dev. & Kurtosis & $\begin{array}{c}\text { Jarque- } \\
\text { Bera }\end{array}$ & Probability \\
\hline Belgium - BE & 311699.5 & 410247 & 221430.6 & 64637.61 & 1.59 & 1.73 & 0.42 \\
\hline Bulgaria - BG & 26257.68 & 45286.5 & 8083 & 13018 & 1.41 & 2.25 & 0.32 \\
\hline $\begin{array}{l}\text { Czech } \\
\text { Republic - CZ }\end{array}$ & 111135.4 & 168473.3 & 45724.2 & 44960.94 & 1.38 & 2.33 & 0.31 \\
\hline Denmark - DK & 209581.6 & 271786.1 & 141441.5 & 41704.53 & 1.70 & 1.58 & 0.45 \\
\hline Germany - DE & 2382533 & 3032820 & 1958532 & 330925.9 & 2.02 & 1.42 & 0.49 \\
\hline Estonia - EE & 11464.88 & 20251.7 & 2902.3 & 5802.74 & 1.55 & 1.85 & 0.40 \\
\hline Ireland - IE & 147099.5 & 262037.4 & 52944.6 & 53285.31 & 2.55 & 0.26 & 0.88 \\
\hline Greece - EL & 177812.3 & 241990.4 & 104662.1 & 41369.17 & 1.95 & 1.00 & 0.61 \\
\hline Spain - ES & 854439.9 & 1116207 & 468878.7 & 230951.4 & 1.59 & 2.38 & 0.31 \\
\hline France - FR & 1744329 & 2194243 & 1231447 & 319521.8 & 1.65 & 1.76 & 0.42 \\
\hline Croatia - HR & 34392.46 & 48129.8 & 17326.6 & 10556.65 & 1.47 & 2.31 & 0.32 \\
\hline
\end{tabular}


End of Table 1

\begin{tabular}{|l|c|c|c|c|c|c|c|}
\hline \multicolumn{1}{|c|}{ Country } & Mean & Maximum & Minimum & Std. Dev. & Kurtosis & $\begin{array}{c}\text { Jarque- } \\
\text { Bera }\end{array}$ & Probability \\
\hline Italy - IT & 1410769 & 1645439 & 895336.2 & 234591.7 & 2.24 & 2.35 & 0.31 \\
\hline Cyprus - CY & 14408.86 & 19731.1 & 7596.1 & 4286.52 & 1.56 & 2.06 & 0.36 \\
\hline Latvia - LV & 14570.15 & 24368.3 & 4136.9 & 7231.72 & 1.47 & 2.06 & 0.36 \\
\hline Lithuania - LT & 21550.06 & 37330.5 & 5124.1 & 10675.94 & 1.58 & 1.77 & 0.41 \\
\hline $\begin{array}{l}\text { Luxembourg - } \\
\text { LU }\end{array}$ & 31834.18 & 52339.7 & 16508.3 & 11443.1 & 1.80 & 1.45 & 0.48 \\
\hline Hungary - HU & 78294.67 & 109674.2 & 35364.5 & 26339.43 & 1.63 & 2.40 & 0.30 \\
\hline Malta - MT & 5445.96 & 9272.9 & 2829 & 1766.37 & 2.47 & 0.93 & 0.63 \\
\hline $\begin{array}{l}\text { Netherlands - } \\
\text { NL }\end{array}$ & 534351.3 & 683457 & 341584.8 & 114404.4 & 1.73 & 1.91 & 0.38 \\
\hline Austria - AT & 256242.5 & 339896 & 183907.2 & 52020.21 & 1.63 & 1.67 & 0.43 \\
\hline Poland - PL & 265790.3 & 430037.8 & 108715.7 & 105493.3 & 1.56 & 1.87 & 0.39 \\
\hline Portugal - PT & 148991.9 & 179929.8 & 91024.7 & 29907.6 & 2.04 & 2.35 & 0.31 \\
\hline Romania - RO & 86922.34 & 159963.7 & 28763 & 48240.44 & 1.33 & 2.48 & 0.29 \\
\hline Slovenia - SI & 28942.18 & 38570 & 16279.8 & 7823.892 & 1.54 & 2.09 & 0.35 \\
\hline Slovakia - SK & 44738.2 & 78685.6 & 15259.4 & 23521.46 & 1.35 & 2.47 & 0.29 \\
\hline Finland - FI & 162133.9 & 209581 & 102650.9 & 35290.18 & 1.77 & 1.63 & 0.44 \\
\hline Sweden - SE & 322118.5 & 447009.5 & 201841.2 & 75167.31 & 1.91 & 1.25 & 0.53 \\
\hline $\begin{array}{l}\text { United } \\
\text { Kingdom - UK }\end{array}$ & 1825918 & 2580065 & 1009479 & 377741.2 & 3.11 & 0.70 & 0.71 \\
\hline
\end{tabular}

The renewable energy consumption series for the countries in this study follows a normal distribution. It should be noted that France has the highest average per-capita power consumption in UE $(9,956.1$ TOE), with a standard deviation of 1,075.5. Malta reports the lowest average in UE with 2.661905 TOE consumed annually, and a standard deviation of 3.90621. Distribution shows positive asymmetry at all states, which means that during the analyzed period, final consumption of renewable energy (FECRE) had a trend of growth, and the distribution is platykurtic, except for Estonia and Romania which have a leptokurtic distribution (see Table 2).

Table 2. Descriptive statistics: FECRE - in TOE

\begin{tabular}{|l|c|c|c|c|c|c|c|}
\hline Country & Mean & Maximum & Minimum & Std. Dev. & Kurtosis & Jarque-Bera & Probability \\
\hline BE & 863.77 & 1731.00 & 337.10 & 519.42 & 1.67 & 2.71 & 0.26 \\
\hline BG & 712.84 & 1206.50 & 178.00 & 317.55 & 2.12 & 0.69 & 0.71 \\
\hline CZ & 1769.53 & 2728.80 & 1122.60 & 556.47 & 1.77 & 2.06 & 0.36 \\
\hline DK & 945.43 & 1447.90 & 559.10 & 310.02 & 1.40 & 2.28 & 0.32 \\
\hline
\end{tabular}


End of Table 2

\begin{tabular}{|l|c|c|c|c|c|c|c|}
\hline Country & Mean & Maximum & Minimum & Std. Dev. & Kurtosis & Jarque-Bera & Probability \\
\hline DE & 8458.49 & 13962.00 & 2727.40 & 3812.41 & 1.48 & 2.06 & 0.36 \\
\hline EE & 468.25 & 550.50 & 282.10 & 60.03 & 5.44 & 11.04 & 0.00 \\
\hline IE & 190.24 & 331.80 & 91.90 & 81.51 & 1.71 & 1.94 & 0.38 \\
\hline EL & 1151.92 & 1514.70 & 982.10 & 166.57 & 2.30 & 2.80 & 0.25 \\
\hline ES & 4231.34 & 6256.60 & 3257.00 & 930.67 & 2.18 & 2.31 & 0.31 \\
\hline FR & 9956.11 & 12203.70 & 8344.80 & 1075.53 & 2.20 & 1.50 & 0.47 \\
\hline HR & 1163.78 & 1262.00 & 1002.10 & 75.46 & 2.24 & 1.22 & 0.54 \\
\hline IT & 4951.91 & 9230.30 & 1314.70 & 3121.58 & 1.35 & 2.45 & 0.29 \\
\hline CY & 66.80 & 107.90 & 38.20 & 27.82 & 1.32 & 2.99 & 0.22 \\
\hline LV & 954.76 & 1096.90 & 824.00 & 74.41 & 2.20 & 0.81 & 0.67 \\
\hline LT & 658.69 & 759.00 & 447.90 & 95.06 & 2.61 & 3.24 & 0.20 \\
\hline LU & 55.93 & 133.20 & 15.40 & 43.18 & 1.51 & 2.46 & 0.29 \\
\hline HU & 1207.93 & 2426.10 & 657.10 & 654.57 & 2.06 & 4.00 & 0.14 \\
\hline MT & 2.66 & 11.00 & 0.10 & 3.91 & 2.66 & 4.90 & 0.09 \\
\hline NL & 763.20 & 1230.90 & 447.30 & 294.72 & 1.39 & 2.68 & 0.26 \\
\hline AT & 2931.58 & 3982.80 & 2179.60 & 616.24 & 1.54 & 2.19 & 0.33 \\
\hline PL & 4291.11 & 5628.00 & 3477.00 & 776.56 & 1.78 & 3.01 & 0.22 \\
\hline PT & 2450.94 & 2803.30 & 2132.40 & 181.45 & 2.60 & 0.14 & 0.93 \\
\hline RO & 3124.54 & 4046.40 & 1281.60 & 691.73 & 3.51 & 2.85 & 0.24 \\
\hline SI & 453.64 & 682.00 & 222.80 & 149.40 & 1.81 & 1.25 & 0.53 \\
\hline SK & 321.22 & 635.30 & 71.10 & 185.68 & 1.76 & 1.36 & 0.51 \\
\hline FI & 4611.71 & 5413.60 & 3944.00 & 387.71 & 2.86 & 0.48 & 0.79 \\
\hline SE & 5297.04 & 6528.80 & 4450.00 & 617.78 & 2.13 & 0.84 & 0.66 \\
\hline UK & 1519.06 & 3766.00 & 485.70 & 1160.33 & 1.93 & 2.89 & 0.24 \\
\hline
\end{tabular}

\section{Empirical findings and Results}

\subsection{Investigation of Model (1)}

\section{Results of unit roots tests}

The time series properties of the variables in Eq. (1) are evaluated by means of two different unit root tests, namely $\mathrm{ADF}$ and PP. We find that for most of the countries the three time series are stationary in their first difference, at least at $10 \%$ level. The results are displayed in Table 3. 
Table 3. Results of the unit roots tests, 1995-2015. Variables LGDP, LFECRE

\begin{tabular}{|c|c|c|c|c|c|c|c|c|}
\hline \multirow{3}{*}{$\mathrm{Co}^{1}$} & \multicolumn{4}{|c|}{$\mathrm{ADP}$} & \multicolumn{4}{|c|}{ PP } \\
\hline & \multicolumn{2}{|c|}{ Level } & \multicolumn{2}{|c|}{ First difference } & \multicolumn{2}{|c|}{ Level } & \multicolumn{2}{|c|}{ First difference } \\
\hline & $\begin{array}{c}\mathrm{L} \\
\text { GDP }\end{array}$ & $\begin{array}{c}\mathrm{L} \\
\text { FECRE }\end{array}$ & $\begin{array}{c}\mathrm{L} \\
\text { GDP }\end{array}$ & $\begin{array}{c}\mathrm{L} \\
\text { FECRE }\end{array}$ & $\begin{array}{c}\mathrm{L} \\
\text { GDP }\end{array}$ & $\begin{array}{c}\mathrm{L} \\
\text { FECRE }\end{array}$ & $\begin{array}{c}\mathrm{L} \\
\text { GDP }\end{array}$ & $\begin{array}{c}\mathrm{L} \\
\text { FECRE }\end{array}$ \\
\hline $\mathrm{BE}$ & -0.66 & -0.24 & $-3.57^{\star *}$ & $-4.3^{* * *}$ & -0.64 & -0.26 & $-3.55^{\star *}$ & $-4.3^{* * *}$ \\
\hline BG & -2.87 & $-3.68^{\star *}$ & $-7.0^{\star * \star}$ & $-4.4^{* \star \star}$ & -0.48 & $-3.13^{\star *}$ & $-6.57^{\star * *}$ & $-4.4^{* \star \star}$ \\
\hline $\mathrm{CZ}$ & -2.02 & 0.27 & $-3.77^{\star *}$ & $-4.5^{\star \star \star}$ & -2.02 & 1.18 & $-3.78^{\star \star}$ & $-5.5^{\star \star \star}$ \\
\hline $\mathrm{DK}$ & -1.99 & -0.25 & $-4.2^{\star * \star}$ & $-4.6^{* \star *}$ & -2.14 & -0.20 & $-4.17^{\star \star \star}$ & $-4.6^{\star \star \star}$ \\
\hline $\mathrm{DE}$ & 1.08 & -1.78 & $-4.9^{\star * *}$ & $-5.3^{\star \star \star}$ & $4.37^{\star * *}$ & $-4.2^{\star * *}$ & $-4.88^{\star \star \star}$ & $-5.3^{* \star *}$ \\
\hline $\mathrm{EE}$ & -2.46 & $-6.7^{* * *}$ & $-3.41^{\star *}$ & $-8.6^{* \star *}$ & $-2.72^{\star}$ & $-6.1^{* * *}$ & $-3.30^{* *}$ & $-9.6^{* \star *}$ \\
\hline IE & -0.01 & -0.60 & -1.54 & $-6.6^{* * *}$ & -2.06 & -0.36 & -1.10 & $-7.2^{\star * *}$ \\
\hline EL & -1.75 & 1.95 & -1.62 & $-5.3^{* \star \star}$ & -2.26 & -0.22 & -1.62 & $-6.7^{\star * \star}$ \\
\hline ES & -1.52 & -0.66 & -1.54 & $-4.0^{* * \star}$ & -2.46 & -0.66 & -1.54 & $-4.0^{* * *}$ \\
\hline FR & -2.10 & -1.38 & $-3.19^{\star *}$ & $-5.5^{* \star \star}$ & -2.30 & -1.38 & $-3.20^{* *}$ & $-5.6^{\star * \star}$ \\
\hline HR & -1.78 & -0.70 & -2.40 & $-4.8^{\star \star \star}$ & -2.33 & $-3.34^{\star *}$ & -2.36 & $-6.5^{\star * \star}$ \\
\hline IT & $-5.9^{\star * * *}$ & -0.95 & $-4.6^{\star * *}$ & $-4.0^{* * \star}$ & $-6.7^{\star * \star}$ & -0.95 & $-4.56^{* * *}$ & $-4.0^{* * \star}$ \\
\hline $\mathrm{CY}$ & -2.45 & -0.43 & -1.59 & -2.64 & -2.44 & -0.28 & -1.59 & $-2.69^{*}$ \\
\hline LV & -1.73 & -1.30 & $-3.76^{\star \star}$ & $-8.3^{* * *}$ & -2.15 & -2.52 & -2.38 & $-10^{* * *}$ \\
\hline LT & $-3.42^{\star *}$ & $-4.9^{\star * \star}$ & $-3.27^{\star \star}$ & $-3.10^{* *}$ & $-5.8^{\star \star \star}$ & $-4.9^{\star * \star}$ & $-3.20^{\star \star}$ & $-3.07^{\star \star}$ \\
\hline $\mathrm{LU}$ & -1.45 & -0.77 & $-4.8^{* * *}$ & -1.93 & -0.62 & -0.29 & $-4.31^{\star * \star}$ & $-5.4^{* * *}$ \\
\hline $\mathrm{HU}$ & -2.25 & -0.15 & $-3.31^{\star *}$ & $-3.9^{* * *}$ & -2.23 & -0.32 & $-3.31^{\star *}$ & $-3.9^{\star * *}$ \\
\hline MT & -0.51 & 0.11 & $-3.31^{* *}$ & $-4.5^{* \star \star}$ & -0.51 & 0.23 & $-3.30^{* *}$ & $-4.5^{* * *}$ \\
\hline NL & $-2.81^{\star}$ & -0.32 & -2.29 & $-4.4^{* * *}$ & $-2.81^{\star}$ & -0.35 & -2.29 & $-4.4^{\star * \star}$ \\
\hline AT & -0.37 & -0.20 & $-4.3^{\star * *}$ & $-6.5^{* \star *}$ & -0.37 & -0.62 & $-3.08^{\star \star}$ & $-6.4^{\star * \star}$ \\
\hline $\mathrm{PL}$ & -1.67 & 0.16 & $-4.28^{* * *}$ & $-3.63^{* *}$ & -2.34 & -0.04 & $-4.47^{\star \star *}$ & $-3.7^{\star *}$ \\
\hline $\mathrm{PT}$ & $-4.7^{\star * *}$ & -2.62 & -1.83 & $-3.21^{\star *}$ & $-4.2^{\star * *}$ & -1.34 & -1.73 & $-5.0^{\star * *}$ \\
\hline RO & -0.82 & $-4.6^{* * *}$ & $-3.56^{\star *}$ & $-5.25^{\star * *}$ & -0.81 & $-4.12^{\star \star *}$ & $-3.56^{\star *}$ & $-7.35^{\star * *}$ \\
\hline SI & -2.53 & -1.35 & -2.43 & $-5.32^{\star * *}$ & -2.53 & -1.15 & -2.41 & $-6.31^{\star * *}$ \\
\hline SK & -1.35 & -1.11 & $-2.76^{\star}$ & $-4.81^{\star * \star}$ & -1.20 & -1.11 & $-2.76^{\star}$ & $-4.81^{\star * \star}$ \\
\hline FI & $-3.01^{*}$ & 0.66 & $-3.36^{\star *}$ & $-4.89^{* * *}$ & $-6.55^{\star * *}$ & -1.40 & $-3.35^{\star *}$ & $-7.35^{\star * *}$ \\
\hline SE & -1.20 & -0.55 & $-4.7^{\star * *}$ & $-5.59^{* * *}$ & -1.71 & -0.38 & $-11.79^{\star * *}$ & $-5.50^{\star * *}$ \\
\hline UK & -2.30 & 0.42 & $-3.01^{\star}$ & -2.63 & -2.30 & -0.06 & $-3.01^{\star}$ & $-2.65^{\star}$ \\
\hline
\end{tabular}

Note: ${ }^{*}$ Denotes significance at $10 \%$ level, ${ }^{* *}$ denotes significance at $5 \%$ level, ${ }^{* *}$ denotes significance at $1 \%$ level.

1 - Country.

Note that for some countries, namely, Ireland, Greece, Spain, Croatia, Cyprus, Slovenia, the null hypothesis of the existence of a unit root cannot be rejected at level and first difference. 


\section{Results of cointegration test}

The next step is to test whether the variables in Eq. (1) are cointegrated. The results for the Johansen test for each cross-section we performed are indicating the existence of a cointegrated relation between the two variables at the $5 \%$ significance level.

Estimation of regression parameters in Eq. (1)

The parameter estimates for Eq. (1) are reported in Table 4.

Table 4. Estimated coefficients of Eq. (1), 1995-2015

\begin{tabular}{|c|c|c|c|c|c|c|}
\hline \multirow{2}{*}{ Country } & \multicolumn{3}{|c|}{$\alpha_{i}$} & \multicolumn{3}{|c|}{$\beta_{i}$} \\
\cline { 2 - 7 } & Coefficient & Std. Error & Prob. & Coefficient & Std. Error & Prob. \\
\hline BE & 10.38390 & 0.132924 & $(0.0000)$ & 0.340772 & 0.020099 & $(0.0000)$ \\
\hline BG & 4.163418 & 0.563997 & $(0.0000)$ & 0.911948 & 0.087229 & $(0.0000)$ \\
\hline CZ & 1.244813 & 0.788123 & $(0.1150)$ & 1.383601 & 0.105952 & $(0.0000)$ \\
\hline DK & 8.225621 & 0.229344 & $(0.0000)$ & 0.589529 & 0.033699 & $(0.0000)$ \\
\hline DE & 12.54059 & 0.197413 & $(0.0000)$ & 0.239162 & 0.022086 & $(0.0000)$ \\
\hline EE & -3.286867 & 5.129005 & $(0.5220)$ & 2.032797 & 0.835142 & $(0.0153)$ \\
\hline FR & 6.959512 & 3.396409 & $(0.0411)$ & 0.803815 & 0.369131 & $(0.0300)$ \\
\hline IT & 12.31442 & 0.162127 & $(0.0000)$ & 0.221537 & 0.019542 & $(0.0000)$ \\
\hline LV & -27.86485 & 8.205739 & $(0.0007)$ & 5.439418 & 1.196346 & $(0.0000)$ \\
\hline LT & -13.45218 & 1.863431 & $(0.0000)$ & 3.593342 & 0.287524 & $(0.0000)$ \\
\hline LU & 8.838033 & 0.121003 & $(0.0000)$ & 0.398686 & 0.032043 & $(0.0000)$ \\
\hline HU & 7.857042 & 1.084469 & $(0.0000)$ & 0.479321 & 0.155066 & $(0.0021)$ \\
\hline MT & 8.622835 & 0.029064 & $(0.0000)$ & 0.168568 & 0.015955 & $(0.0000)$ \\
\hline NL & 9.625808 & 0.384441 & $(0.0000)$ & 0.538966 & 0.058452 & $(0.0000)$ \\
\hline AT & 4.865478 & 0.516501 & $(0.0000)$ & 0.950496 & 0.064845 & $(0.0000)$ \\
\hline PL & -5.469257 & 2.412223 & $(0.0239)$ & 2.141022 & 0.288843 & $(0.0000)$ \\
\hline PT & 8.402356 & 5.261543 & $(0.1110)$ & 0.447017 & 0.674389 & $(0.5078)$ \\
\hline RO & -2.756097 & 2.966054 & $(0.3533)$ & 1.740359 & 0.369753 & $(0.0000)$ \\
\hline SK & 6.843028 & 0.373631 & $(0.0000)$ & 0.671583 & 0.066908 & $(0.0000)$ \\
\hline FI & -7.321296 & 3.075913 & $(0.0178)$ & 2.287777 & 0.364729 & $(0.0000)$ \\
\hline SE & 1.755877 & 3.104853 & $(0.5720)$ & 1.272172 & 0.362327 & $(0.0005)$ \\
\hline UK & 13.59643 & 0.455429 & $(0.0000)$ & 0.113230 & 0.064273 & $(0.0788)$ \\
\hline
\end{tabular}

Note: Figures in parenthesis indicate the $p$-values of the $t$-statistic.

The test results in Table 4 show that the coefficients determined for this linear regression are not significant on the 5\% level for Czech Republic, Estonia, Portugal, Romania, Sweden and United Kingdom. Consequently, for these countries this regression model is not relevant for the impact of renewable energy consumption on real GDP. 
Analyzing the values of the estimated regression coefficients $\hat{\beta}_{i}$ corresponding to the variable $L F E C R E_{i}$ we note that:

- all coefficients $\hat{\beta}_{i}$ are positive, indicating a favourable impact of renewable energy consumption on economic growth;

- most of these coefficients are smaller than 1, indicating that the impact of renewable energy consumption on economic growth is not very significant.

\section{Granger causality test}

In Table 5 below the results of the Granger causality test between variables LGDP and LFECRE are presented.

Table 5. Granger causality test between variables $L G D P$ and $L F E C R E$

\begin{tabular}{|c|c|c|c|c|c|c|}
\hline \multirow{3}{*}{ Country } & \multicolumn{3}{|c|}{ Null hypothesis 1} & \multicolumn{3}{|c|}{ Null hypothesis 2} \\
\hline & \multicolumn{3}{|c|}{ FECRE does not Granger-cause GDP } & \multicolumn{3}{|c|}{ GDP does not Granger-cause FECRE } \\
\hline & F-Statistic & Prob. & Conclusion & F-Statistic & Prob. & Conclusion \\
\hline $\mathrm{BE}$ & 0.65358 & 0.5353 & Reject & 4.56935 & $0.0297^{\star}$ & Accept \\
\hline BG & 5.95958 & $0.0134^{*}$ & Accept & 1.74518 & 0.2105 & Reject \\
\hline $\mathrm{CZ}$ & 1.32485 & 0.2972 & Reject & 3.4755 & 0.0595 & Reject \\
\hline $\mathrm{DK}$ & 1.17643 & 0.3371 & Reject & 5.69495 & $0.0155^{\star}$ & Accept \\
\hline $\mathrm{DE}$ & 3.79739 & $0.0481^{*}$ & Accept & 2.27835 & 0.1391 & Reject \\
\hline $\mathrm{EE}$ & 0.51602 & 0.6078 & Reject & 7.91565 & $0.005^{*}$ & Accept \\
\hline IE & 2.81378 & 0.0939 & Reject & 1.47453 & 0.2623 & Reject \\
\hline EL & 0.12543 & 0.8831 & Reject & 2.23086 & 0.1442 & Reject \\
\hline ES & 0.49676 & 0.6188 & Reject & 3.79123 & $0.0483^{*}$ & Accept \\
\hline FR & 1.94312 & 0.18 & Reject & 4.88416 & $0.0246^{\star}$ & Accept \\
\hline HR & 0.05533 & 0.9464 & Reject & 1.75416 & 0.209 & Reject \\
\hline IT & 0.53497 & 0.5972 & Reject & 7.59174 & $0.0058^{\star}$ & Accept \\
\hline $\mathrm{CY}$ & 2.26656 & 0.1404 & Reject & 3.0712 & 0.0784 & Reject \\
\hline LV & 4.41984 & $0.0325^{\star}$ & Accept & 2.96017 & 0.0847 & Reject \\
\hline $\mathrm{LT}$ & 0.89086 & 0.4323 & Reject & 2.01394 & 0.1703 & Reject \\
\hline $\mathrm{LU}$ & 0.23248 & 0.7956 & Reject & 3.19939 & 0.0717 & Reject \\
\hline $\mathrm{HU}$ & 0.0489 & 0.9524 & Reject & 10.6123 & $0.0016^{\star}$ & Accept \\
\hline MT & 4.33689 & $0.0342^{*}$ & Accept & 4.72027 & $0.0271^{\star}$ & Accept \\
\hline $\mathrm{NL}$ & 1.41077 & 0.2766 & Reject & 3.28738 & 0.0675 & Reject \\
\hline AT & 0.42477 & 0.6621 & Reject & 2.90071 & 0.0883 & Reject \\
\hline $\mathrm{PL}$ & 1.12563 & 0.3521 & Reject & 3.51953 & 0.0578 & Reject \\
\hline $\mathrm{PT}$ & 0.83213 & 0.4555 & Reject & 7.16003 & $0.0072^{\star}$ & Accept \\
\hline $\mathrm{RO}$ & 0.11874 & 0.8889 & Reject & 6.97199 & $0.0079^{\star}$ & Accept \\
\hline SI & 1.22431 & 0.3236 & Reject & 5.77281 & $0.0148^{\star}$ & Accept \\
\hline SK & 1.93489 & 0.1812 & Reject & 0.93412 & 0.4161 & Reject \\
\hline
\end{tabular}


End of Table 5

\begin{tabular}{|c|c|c|c|c|c|c|}
\hline \multirow{2}{*}{ Country } & \multicolumn{3}{|c|}{ Null hypothesis 1 } & \multicolumn{3}{c|}{ Null hypothesis 2 } \\
\cline { 2 - 7 } & \multicolumn{2}{|c|}{ FECRE does not Granger-cause GDP } & \multicolumn{2}{c|}{ GDP does not Granger-cause FECRE } \\
\cline { 2 - 7 } & F-Statistic & Prob. & Conclusion & F-Statistic & Prob. & Conclusion \\
\hline FI & 0.94581 & 0.4118 & Reject & 1.89279 & 0.1872 & Reject \\
\hline SE & 1.22431 & 0.3236 & Reject & 5.77281 & $0.0148^{\star}$ & Accept \\
\hline UK & 4.48207 & $0.0313^{\star}$ & Accept & 2.49925 & 0.118 & Reject \\
\hline
\end{tabular}

Note: ${ }^{\star}$ Denotes that the null hypothesis is accepted at 0.05 level.

The conclusions emphasized within this table have the following significance:

- "Accept" - means that the null hypothesis is accepted, that is the left variable does not Granger-cause the right corresponding variable;

- "Reject" - means that the null hypothesis is rejected, that is the left variable does Granger-cause the right variable.

Analyzing the results in Table 5 we found:

- bidirectional Granger causality FECRE GDP for 12 countries in the panel, namely Czech Republic, Ireland, Greece, Croatia, Cyprus, Lithuania, Luxembourg, Netherlands, Austria, Poland, Slovakia, Finland;

- unidirectional Granger causality FECRE GDP for 11 countries, namely Belgium, Denmark, Estonia, Spain, France, Italy, Hungary, Portugal, Romania, Slovenia, Sweden;

- unidirectional Granger causality GDP FECRE for 4 countries, namely Bulgaria, Denmark, Latvia, United Kingdom;

- no Granger causality for Malta.

\subsection{Investigation of Model (2)}

First, we analyzed the evolution of the percentage ratio $\frac{F E C R E_{i t}}{F E C_{i t}} \times 100$ with respect to the time, for each individual country. The linear regression of each of $N$ time series shows an increasing trend in the evolution of these ratio for all but one cases. We plotted graphic representations of these time series and of the corresponding regression line. In each sub-figure 1(a), 1(b), 1(c), 1(d) we represented seven of the 28 time series of the panel.

As the trend of the percentage ratio is increasing, we noted that the variation of the graph slope is also generally increasing. This tendency is emphasized empirically, by estimating the regression coefficients $\hat{\gamma}_{i 1}, \ldots, \hat{\gamma}_{i 4}$ over 4 different periods of time, namely 1995-2015, 2000-2015, 2005-2015 and 2010-2015. In addition to the initial period 1995-2015, we also analyzed the other three periods motivated by the shape of the graphs in Figure 1, that could be justified by political decisions in several European Union documents as "EU Sustainable Development Strategy" adopted at Goteborg (2001) and revised in 2006 and "EU Directive 2009/28/EC".

The FMOLS regression test performed in EViews showed that for each cross section the estimated coefficient is highly significant, as all the corresponding probabilities are 0 .

The values of the cross-sections regression coefficients for the above four time periods are given in Table 6 below. 


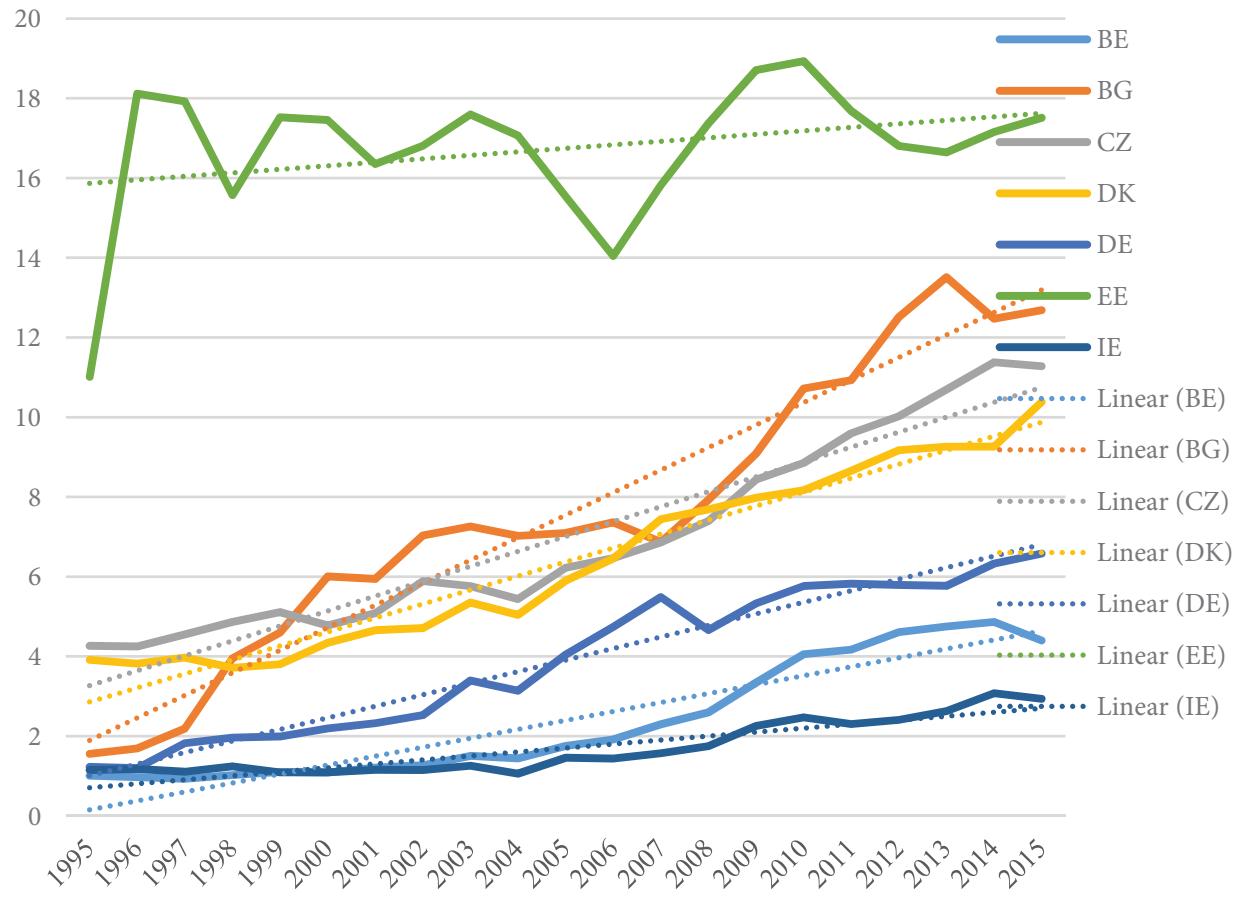

Figure 1(a). Evolution FECRE share in FEC between 1995-2015:

Belgium, Bulgaria, Czech Republic, Denmark, Germany, Estonia, Ireland

30
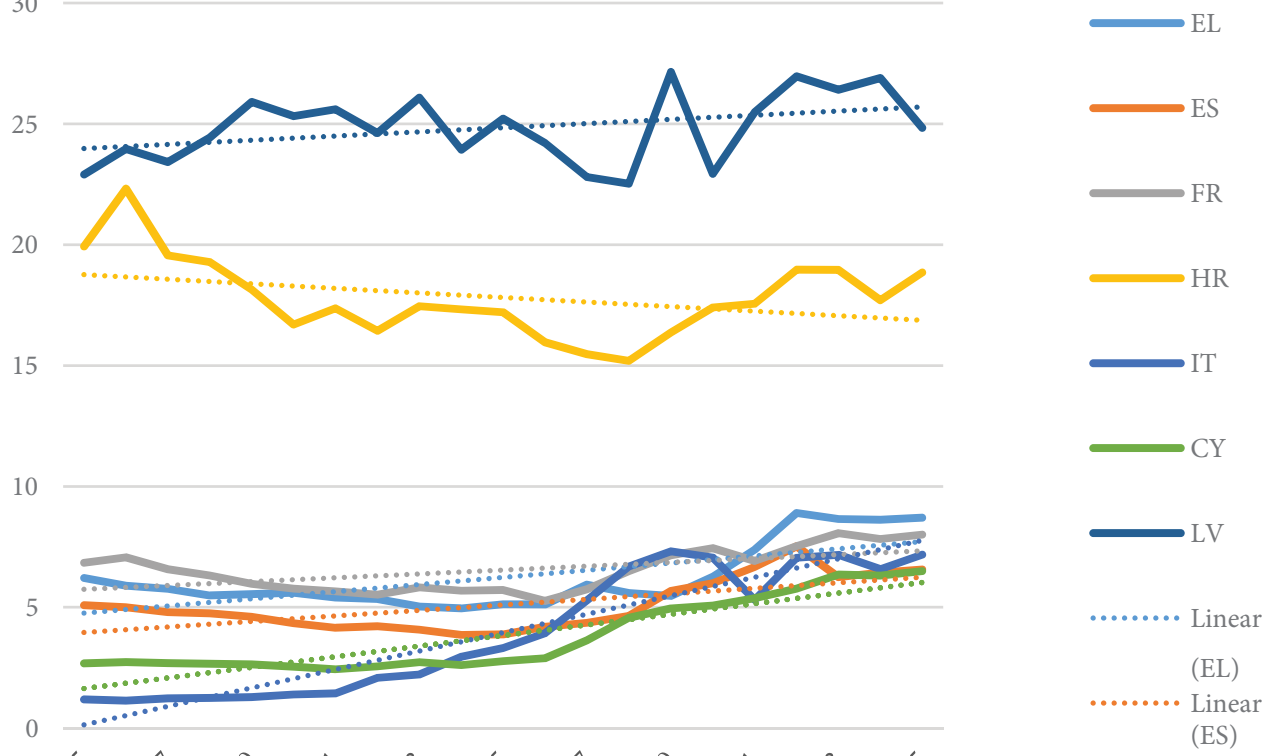

10

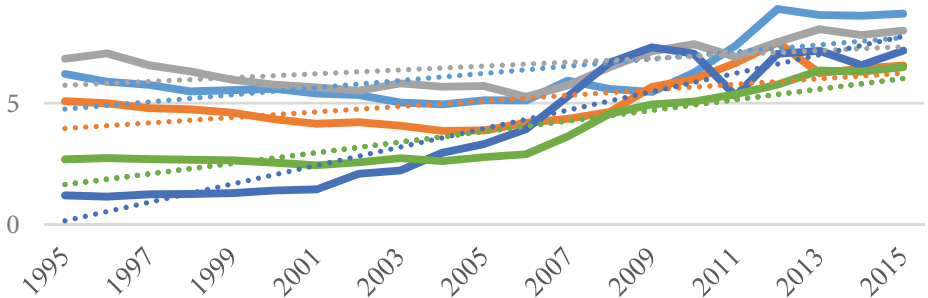

Figure 1(b). Evolution FECRE share in FEC between 1995-2015:

Greece, Spain, France, Croatia, Italy, Cyprus, Latvia 


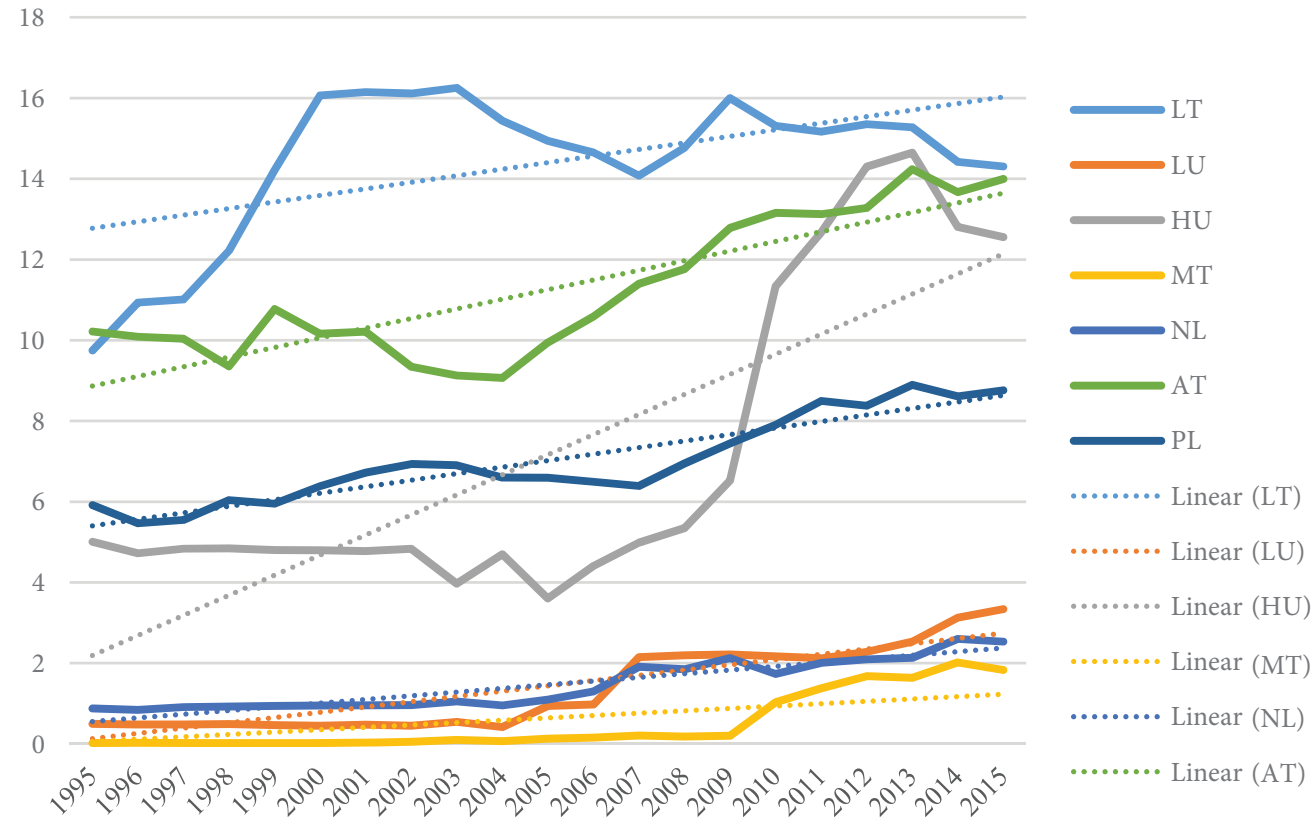

Figure 1(c). Evolution FECRE share in FEC between 1995-2015:

Lithuania, Luxembourg, Hungary, Malta, Netherlands, Austria, Poland

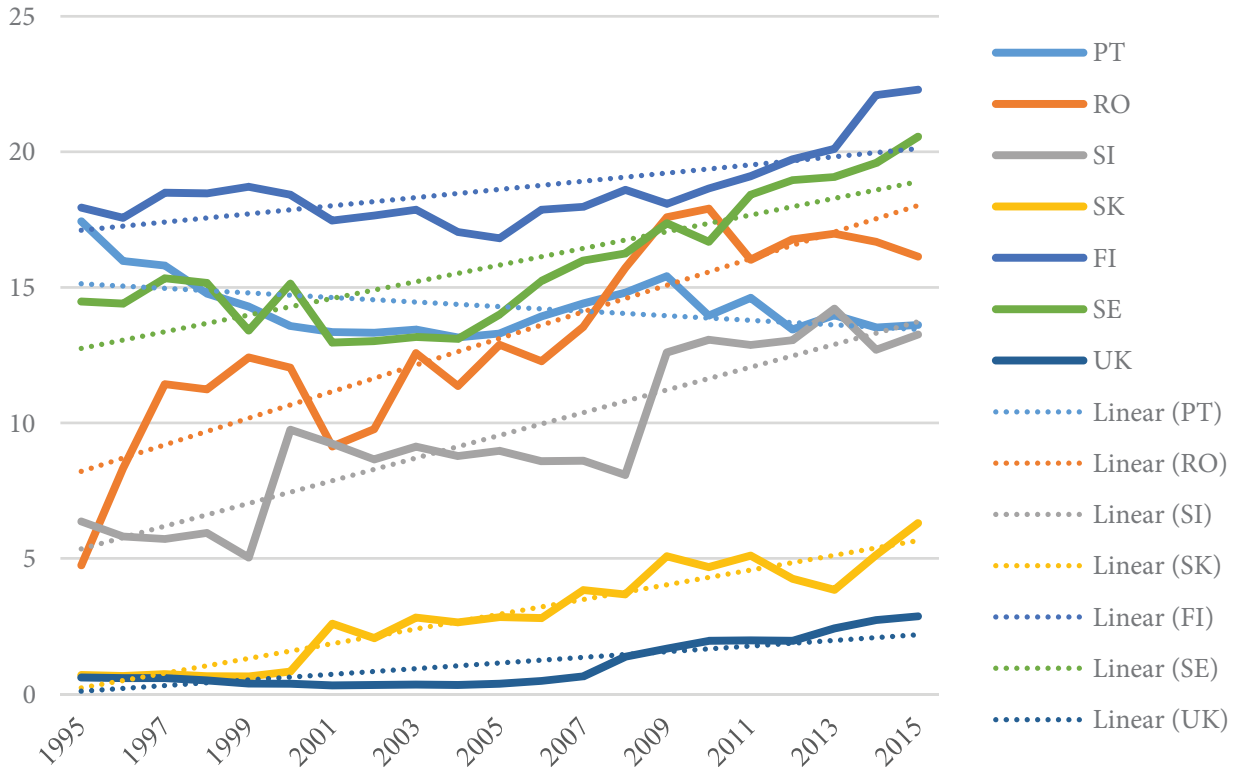

Figure 1(d). Evolution FECRE share in FEC between 1995-2015: Portugal, Romania, Slovenia, Slovakia, Finland, Sweden, United Kingdom 
Table 6. Estimation of regression coefficients over four periods of time

\begin{tabular}{|c|c|c|c|c|}
\hline \multicolumn{5}{|c|}{ Regression Coefficient $\gamma$} \\
\hline Country & $\hat{\gamma}_{i 1}, 1995-2015$ & $\hat{\gamma}_{i 2}, 2000-2015$ & $\hat{\gamma}_{i 3}, 2005-2015$ & $\hat{\gamma}_{i 4}, 2010-2015$ \\
\hline $\mathrm{BE}$ & 0.023537 & 0.027714 & 0.035007 & 0.043145 \\
\hline BG & 0.071045 & 0.088914 & 0.098652 & 0.121400 \\
\hline $\mathrm{CZ}$ & 0.068951 & 0.07642 & 0.087012 & 0.102707 \\
\hline DK & 0.062904 & 0.070703 & 0.081107 & 0.091045 \\
\hline $\mathrm{DE}$ & 0.038266 & 0.045677 & 0.054677 & 0.060062 \\
\hline $\mathrm{EE}$ & 0.167848 & 0.169451 & 0.169036 & 0.174627 \\
\hline IE & 0.017353 & 0.018401 & 0.021287 & 0.026388 \\
\hline EL & 0.060471 & 0.061212 & 0.065443 & 0.079515 \\
\hline ES & 0.050364 & 0.050761 & 0.054978 & 0.065685 \\
\hline FR & 0.064920 & 0.064773 & 0.068689 & 0.076354 \\
\hline HR & 0.176055 & 0.171238 & 0.171372 & 0.182152 \\
\hline IT & 0.039684 & 0.047111 & 0.059673 & 0.067195 \\
\hline $\mathrm{CY}$ & 0.038966 & 0.041627 & 0.048226 & 0.058229 \\
\hline $\mathrm{LV}$ & 0.247901 & 0.249944 & 0.249595 & 0.255616 \\
\hline LT & 0.143623 & 0.151712 & 0.149120 & 0.149721 \\
\hline LU & 0.014932 & 0.016824 & 0.021406 & 0.025686 \\
\hline $\mathrm{HU}$ & 0.071338 & 0.077860 & 0.092286 & 0.130126 \\
\hline MT & 0.006554 & 0.008521 & 0.011176 & 0.016207 \\
\hline NL & 0.014394 & 0.016101 & 0.019145 & 0.021572 \\
\hline $\mathrm{AT}$ & 0.238987 & 0.269943 & 0.338731 & 0.338731 \\
\hline PL & 0.070475 & 0.074745 & 0.077541 & 0.084967 \\
\hline $\mathrm{PT}$ & 0.141819 & 0.138718 & 0.141243 & 0.138833 \\
\hline $\mathrm{RO}$ & 0.127053 & 0.140703 & 0.155305 & 0.167555 \\
\hline SI & 0.097002 & 0.107208 & 0.113816 & 0.131973 \\
\hline SK & 0.028761 & 0.035792 & 0.042504 & 0.048596 \\
\hline FI & 0.185997 & 0.186894 & 0.191519 & 0.202683 \\
\hline SE & 0.156775 & 0.160770 & 0.173861 & 0.188213 \\
\hline UK & 0.010043 & 0.011603 & 0.015951 & 0.023048 \\
\hline
\end{tabular}

Analyzing the data in Table 6 we derive the following conclusions:

- for almost all of the countries in the panel, the regression coefficients estimates $\hat{\gamma}_{i j}$ have increasing values over the four periods of time, that $\hat{\gamma}_{i 1} \leq \hat{\gamma}_{i 2} \leq \hat{\gamma}_{i 3} \leq \hat{\gamma}_{i 4}$; that shows an increasing tendency in the share of renewable energy consumption with respect to the final energy consumption. Only for one of the countries in the panel, namely Portugal, this sequence is decreasing;

- according to these results, for three of the countries in the panel, namely Latvia, Finland, Austria the estimated ratio $\hat{\gamma}_{i 4} \times 100$ is greater than the threshold in the EU directives for the 2020 horizon; 
- the smallest estimate was found for Malta, namely 1.6\%, and for four other countries the estimates are inferior to $3 \%$.

We also point out that the linear regression seams to not be the most appropriate model in order to estimate the trend of the share of renewable energy consumption with respect to the final energy consumption.

\section{Concluding remarks}

This paper aimed to extend the research on the causal relationship between economic growth and renewable energy consumption using a panel of data for 28 countries of European Union over a period from 1995 to 2015.

The empirical results showed a positive impact, although statistical small, of renewable energy consumption on economic growth. Also, causalities were found between these two macroeconomics indicators, showing either bidirectional or unidirectional Granger-cause for each country in the panel.

The results obtained in this paper justify the political decisions of EU concerning the necessity of increasing the renewable energy consumption. They also prove that this type of energy consumption has a positive impact on economic growth. Thus, the inclusion of such politics in future EU and national strategies is further motivated.

In addition, motivated by EU Directive 2009/28/EC stating that the share of renewable energy consumption into the final energy consumption should reach $20 \%$ by 2020 , we analyzed the tendency of these ratio within the data panel.

By means of linear regression, an increasing trend was found for the ratio between renewable energy consumption and final energy consumption for all but one of the EU countries. Finally, using four different time period within the analyzed 1995-2015 one, we found that the estimated ratio are also increasing. Nevertheless, the empirical results showed that a nonlinear estimate should be more appropriate, which we intend to perform into a future study.

\section{References}

Alper, A., \& Oguz, O. (2016). The role of renewable energy consumption in economic growth: Evidence from asymmetric causality. Renewable and Sustainable Energy Reviews, 60, 953-959. https://doi.org/10.1016/j.rser.2016.01.123

Anwar, A., Arshed, N., \& Nabeela Kousar, N. (2017). Renewable Energy Consumption and Economic Growth in Member of OIC Countries. European Online Journal of Natural and Social Sciences, 6(1), 111-129.

Apergis, N., \& Danuletiu, D. (2014). Renewable energy and economic growth: Evidence from the sign of panel long-run causality. International Journal of Energy Economics and Policy, 4(4), 578-587.

Apergis, N., \& Payne, J. (2010a). Renewable energy consumption and growth in Eurasia. Energy Economics, 32, 1392-1397. https://doi.org/10.1016/j.eneco.2010.06.001

Apergis, N., \& Payne, J. (2010b). Renewable energy consumption and economic growth: Evidence from a panel of OECD countries. Energy Policy, 38(1), 656-660. https://doi.org/10.1016/j.enpol.2009.09.002

Apergis, N., \& Payne, J. (2011a). Renewable and non-renewable energy consumption-growth nexus: Evidence from emerging market economics. Applied Energy, 88, 5226-5230.

https://doi.org/10.1016/j.apenergy.2011.06.041 
Apergis, N., \& Payne, J. (2011b). The renewable energy consumption - growth nexus in Central America. Applied Energy, 88, 343-347. https://doi.org/10.1016/j.apenergy.2010.07.013

Apergis, N., \& Payne, J. (2012). Renewable and non-renewable energy consumption-growth nexus: Evidence from a panel error correction model. Energy Economics, 34, 733-738. https://doi.org/10.1016/j.eneco.2011.04.007

Aslan, A. (2013). Energy consumption and GDP: The strong relationship in OECD countries. Journal Energy Sources, Part B: Economics, Planning, and Policy, 8(4), 339-345. https://doi.org/10.1080/15567240903502586

Bhattacharya, M., Paramati, S., Ozturk, I., \& Bhattacharya, S. (2016). The effect of renewable energy consumption on economic growth: Evidence from top 38 countries. Applied Energy, 162, 733-741. https://doi.org/10.1016/j.apenergy.2015.10.104

Bloomberg New Energy Finance (BNEF). (2016). Global trends in renewable energy investment 2016. 84 p. Frankfurt School-UNEP Centre. Retrieved from http://fs-unep-centre.org/sites/default/files/ publications/globaltrendsinrenewableenergyinvestment2016lowres_0.pdf

Bobinaite, V., Juozapaviciene, A., \& Konstantinaviciute, I. (2011). Assessment of causality relationship between renewable energy consumption and economic growth in Lithuania. Engineering Economics, 22(5), 510-518. https://doi.org/10.5755/j01.ee.22.5.969

Bozkurt, C., \& Destek, M. (2015). Renewable energy and sustainable development nexus in selected OECD countries. International Journal of Energy Economics and Policy, 5(2), 507-514.

Chontanawat, J., Hunt, L., \& Pierse, R. (2008). Does energy consumption cause economic growth? Evidence from a systematic study of over 100 countries. Journal of Policy Modeling, 30, 209-220. https://doi.org/10.1016/j.jpolmod.2006.10.003

Dalla Longa, F., \& van der Zwaan, B. (2017). Do Kenya's climate change mitigation ambitions necessitate large-scale renewable energy deployment and dedicated low-carbon energy policy?, Renewable Energy, 113, 1559-1568. https://doi.org/10.1016/j.renene.2017.06.026

Dickey, D. A., \& Fuller, W. A. (1981). Likelihood ratio statistics for autoregressive time series with a unit root. Econometrica, 49, 1057-1072. https://doi.org/10.2307/1912517

Directive 2009/28/EC of the European Parliament and of the Council of 23 April 2009 on the promotion of the use of energy from renewable sources and amending and subsequently repealing Directives 2001/77/EC and 2003/30/EC. 47 p. Retrieved from http://eur-lex.europa.eu/legal-content/EN/TXT/ $\mathrm{PDF} /$ ?uri=CELEX:32009L0028\&from=RO

Engle, G., \& Granger, C. (1987). Co-Integration and error correction: Representation, estimation, and testing. Econometrica, 55(2), 251-276. https://doi.org/10.2307/1913236

European Parliament. (2016). Promotion of renewable energy sources in the EU, EU policies and Member State approaches, European Union. 24 p. Retrieved from http://www.europarl.europa.eu/RegData/ etudes/IDAN/2016/583810/EPRS_IDA(2016)583810_EN.pdf

Eurostat. Statistics-explained. (2017). Energy production and imports. Retrieved from http://ec.europa. eu/eurostat/statistics-explained/index.php/Energy_production_and_imports

EViews 9 User's Guide I, II. (2015). IHS Global Inc. Retrieved from www.eviews.com

Gasparatos, A., Doll, C. N. H., Esteban, M., Ahmed, A., \& Olang, T. A. (2017). Renewable energy and biodiversity: Implications for transitioning to a Green Economy. Renewable and Sustainable Energy Reviews, 70, 161-184. https://doi.org/10.1016/j.rser.2016.08.030

IEA (International Energy Agency). (2015). Energy and climate change. World energy outlook special report. Retrieved from https://www.iea.org/publications/freepublications/publication/WEO2015SpecialReportonEnergyandClimateChange.pdf

Inglesi-Lotz, R. (2016). The impact of renewable energy consumption to economic growth: A panel data application. Energy Economics, 53, 58-63. https://doi.org/10.1016/j.eneco.2015.01.003 
Jarque, C. M., \& Bera, A. K. (1980). Efficient tests for normality, homoskedasticity and serial independence of regression residuals. Economics Letters, 6, 255-259. https://doi.org/10.1016/0165-1765(80)90024-5

Johansen, S., \& Juselius, K. (1990). Maximum likelihood estimation and inferences on co-integration with approach. Oxford Bulletin of Economics and Statistics, 52, 169-209. https://doi.org/10.1111/j.1468-0084.1990.mp52002003.x

Lin, B., \& Moubarak, M. (2014). Renewable energy consumption-Economic growth nexus for China. Renewable and Sustainable Energy Reviews, 40, 111-117. https://doi.org/10.1016/j.rser.2014.07.128

Mardani, A., Jusoh, A., Nor, K., Khalifah, Z., Zakwan, N., \& Valipour, A. (2015). Multiple criteria decision-making techniques and their applications - a review of the literature from 2000 to 2014. Economic Research, 28(1), 516-571. https://doi.org/10.1080/1331677X.2015.1075139

Ocal, O., \& Aslan, A. (2013). Renewable energy consumption-economic growth nexus in Turkey. Renewable and Sustainable Energy Reviews, 28, 494-499. https://doi.org/10.1016/j.rser.2013.08.036

Okyay, U., Ebru, A., \& Fatih, Y. (2014). Energy consumption and economic growth nexus: Evidence from developed countries in Europe. International Journal of Energy Economics and Policy, 4(3), 411-419.

Ozturk, F. (2017). Energy consumption-GDP causality in MENA countries. Energy Sources, Part B: Economics, Planning, and Policy, 12(3), 231-236. https://doi.org/10.1080/15567249.2015.1072597

Pao, H. T., \& Fu, H. C. (2013). Renewable energy, non-renewable energy and economic growth in Brazil. Renewable and Sustainable Energy Reviews, 25, 381-392. https://doi.org/10.1016/j.rser.2013.05.004

Pedroni, P. (2004). Panel cointegration: asymptotic and finite sample properties of pooled time series tests with an application to the PPP hypothesis: new results. Econ. Theory, 20, 597-627. https://doi.org/10.1017/S0266466604203073

Phillips, C. B., \& Hansen, B. 1990. Statistical inference in instrumental variables regression with I (1) processes. Review of Economics Studies, 57, 99-125. https://doi.org/10.2307/2297545

Phillips, P. C., \& Perron, P. (1988). Testing for a unit root in time series regression. Biometrika, 75, 335-346. https://doi.org/10.1093/biomet/75.2.335

Rafiq, S., \& Salim, R. (2009). Temporal causality between energy consumption and income in six Asian emerging countries. Applied Economics Quarterly, 55(4), 1-16. https://doi.org/10.3790/aeq.55.4.335

Rafiq, S., \& Salim, R. (2011). the linkage between energy consumption and income in six Asian emerging economies: An empirical analysis. International Journal of Emerging Market, 6(1), 50-73. https://doi.org/10.1108/17468801111104377

Sadorsky, P. (2009). Renewable energy consumption and income in emerging economies. Energy Policy, 37(10), 4021-4028. https://doi.org/10.1016/j.enpol.2009.05.003

Salim, R., \& Bloch, H. (2009). Expenditures on business R\&D and trade performance in Australia: Is there a link?. Applied Economics, 41, 351-361. https://doi.org/10.1080/00036840601007302

Stern, D. (2000). A multivariate cointegration analysis of the role of energy in the US economy. Energy Economics, 22, 267-283. https://doi.org/10.1016/S0140-9883(99)00028-6

Tugcu, C. T., Ozlturk, I., \& Aslain, A. (2012). Renewable and non-renewable energy consumption and economic growth revisited: evidence from G7 countries. Energy Econ, 34, 1942-1950. https://doi.org/10.1016/j.eneco.2012.08.021

Wada, I. (2017). Energy production and economic growth in Saudi Arabia: Dynamic causality. Energy Sources, Part B: Economics, Planning and Policy, 12(6), 584-590. https://doi.org/10.1080/15567249.2016.1248872

Yildirim, E., Sarac, S., \& Aslan, A. (2012). Energy consumption and economic growth in the USA: Evidence from renewable energy. Renewable and Sustainable Energy Review, 16(9), 6770-6774. https://doi.org/10.1016/j.rser.2012.09.004 